\title{
A paradigm shift in studies based on rheumatoid arthritis clinical registries
}

\author{
Soo-Kyung Cho and Yoon-Kyoung Sung
}

Department of Rheumatology, Hanyang University Hospital for Rheumatic Diseases, Seoul, Korea

Received: December 11, 2018 Accepted: January 2, 2019

\section{Correspondence to} Yoon-Kyoung Sung, M.D. Department of Rheumatology, Hanyang University Hospital for Rheumatic Diseases, 222-1 Wangsimni-ro, Seongdong-gu, Seoul 04763, Korea

Tel: +82-2-2290-9250

Fax: +82-2-2298-8231

E-mail:sungyk@hanyang.ac.kr
Clinical research is the study of aspects of patient health or illness that are closely related to clinical practice. In the late 2oth and early 21th century, outcomes for patients with rheumatoid arthritis (RA) improved dramatically due to breakthroughs in new drugs. Patient-reported outcome measures now play a significant role in the drug development process as study endpoints in clinical trials of new therapies, and this has led to increased interest in the patient's perspective, drug safety and treatment outcomes in clinical practice. In accordance with these needs, many prospective cohorts for RA patients and registries of biologic disease modifying anti-rheumatic drugs have been actively conducted in the United States and European and Asian countries. A gradual shift is taking place in the major outcomes of clinical research using these prospective cohorts and registries. This article will introduce representative registries for RA in each country set up in the early 2000 s and will discuss future perspectives in clinical research on RA patients using such clinical registries.

Keywords: Arthritis, rheumatoid; Cohort studies; Registries; Patients reported outcomes; Big data

\section{INTRODUCTION}

Rheumatoid arthritis (RA) is a long-term chronic disease whose symptoms include joint pain and difficulty with daily tasks and can progress to joint deformity and reduced quality of life (QoL) [1]. With the advance of years these features can lead to many comorbid conditions in patients. Because of the complexity of the clinical manifestations of RA and the different experiences of patients, long-term observational studies are crucial for understanding treatment outcomes and predicting the prognosis of RA patients [2].

Since the introduction of biologic disease modifying anti-rheumatic drugs (DMARDs) for treating RA in the early 2000s [3], there have been improvements in disease outcomes and patients' QoL. Various outcome measures including disease activity and patient-re- ported outcomes (PROs) have been developed and used widely to estimate the efficacy or safety of new drugs in randomized clinical trials (RCTs) [4]. Eventually, treat to target (T2T) strategies and evidence-based clinical practice guidelines were developed based on these indices [5]. Although these RCTs can reveal the efficacy and safety of drugs, they are still limited by the characteristics of the particular study population in terms of limited exposure, fewer comorbidities and inclusion and exclusion criteria not considered to be exclusionary in general practice [6]. Therefore, many prospective cohort of RA patients and registries of biologic DMARDs have been established in the United States (US) and European and Asian countries [7]. The observational studies recorded provide a great deal of information on the clinical features and long-term outcomes of RA patients and the comparative effectiveness and responsiveness 
of innovative treatments [8-10].

Over the last decades, the main issues examined in studies using these prospective cohorts and registries of RA patients have changed. In this article, we intend to review representative cohort and registries of RA patients in various countries and to describe recent changes in the research issues confronted in these observational studies.

\section{ESTABLISHED RA REGISTRIES AND THEIR MAIN OUTCOMES}

To date, prospective RA cohorts and registries have been established to observe the natural course of the disease, changes in disease activity in response to the various treatment options, and the safety of conventional and innovative treatments. Representative RA cohorts and registries are listed in Table 1 [6,11-17].

In the US, a nationwide cohort using a computer system for collecting data was established in 2002: the Consortium of Rheumatology Researchers of North America (CORRONA) [8]. This database collected clinical information, PRO, toxicities and new medical problems facing RA patients. CORRONA extended the patient spectrum enrolled to psoriatic arthritis (PsA), spondyloarthritis, psoriasis, inflammatory bowel disease in 2015, and is now expanding into the realm of patient-derived data based on applications of mobile devices [6]. Treatment patterns [18], disability [19], and drug safety [20] were the main outcomes of the early studies from the CORRONA. However, over time, studies have come to focus on remission [21], comorbidities [22], and PROs [23].

Cohorts from single centers can have strengths that differ from nationwide cohorts in terms of quality of data, with less missing data and less attrition of participants, even though their generalizability is limited. The Brigham and Women's Hospital Rheumatoid Arthritis Sequential Study (BRASS) cohort was established in a single center in the USA in 2003, and many important results were obtained using this cohort [24]. These included genetic factors influencing disease phenotype and drug responses $[9,25]$, remission $[26,27]$, and predictors of radiographic progression $[28,29]$. Thereafter, multimorbidities became the main focus of studies [30-34].
In European countries, several nationwide registries for biologic DMARDs were established early by government: the Swedish Biologics Register [35] in 1999 [36], a nationwide registry of biological therapies in Denmark [35] in 2000 [37], the Norwegian NOR-DMARD register also in 2000 [38], and the British Society for Rheumatology Biologics Register (BSRBR) in 2001 [39]. A distinctive characteristic of these registries is the ability to retrieve important outcomes by linkage to other nationwide databases for claims or statistics within the individual countries, since they were promoted by government. These registries provided valuable evidence concerning effectiveness and safety issues related to biologic DMARD [40-42] and as long-term observations with registries became possible, malignancy and mortality data have also been reported [43-45].

Recently international collaborative studies have been conducted between countries [46-48], as well as between registries, especially European ones [35,49]. Such collaborations can produce more reliable information because of the greater numbers of patients and generalizability, and they make it possible to identify different patterns of drug use and disease progression in the specific medical environments of each nation.

In Japan, a single center in Tokyo Women's Medical University launched the Institute of Rheumatology Rheumatoid Arthritis (IORRA) cohort in 2000 to improve the management of Japanese RA patients [10]. Early on, the main outcomes of this Japanese cohort were disability $[50,51]$ and fragility, including osteoporosis and fracture [52,53]. On one hand, the Registry of Japanese Rheumatoid Arthritis Patients on Biologics for Long-term safety (REAL) was started in 2005 [54] and reported on drug safety issues, especially infection risks associated with biologic DMARDs [55].

Meanwhile in Korea, a nationwide cohort for RA, the Korean Observational Study Network for Arthritis (KORONA), was created in 2009 by Clinical Research Center for Rheumatoid Arthritis in Hanyang University and funded by the Ministry of Health and Affairs of Korea [56]. A total of 5,371 RA patients over the age of 18 who satisfied the 1987 American College of Rheumatology (ACR) classification criteria for RA were recruited by rheumatologists from 23 centers across Korea as part of KORONA. Through this prospective cohort study, researchers published studies on various outcomes in 
Table 1. Characteristics of RA cohorts and registries in various countries

\begin{tabular}{|c|c|c|c|c|c|}
\hline $\begin{array}{l}\text { Cohort or } \\
\text { registry }\end{array}$ & Start date & Country & Population & $\begin{array}{l}\text { No. of RA } \\
\text { patients }\end{array}$ & Main outcome \\
\hline CORRONA & 2002 & USA & $\begin{array}{l}\text { RA (2001-), SpA, PsA, } \\
\text { Psoriasis (2015-) }\end{array}$ & Over $42,000[6]$ & $\begin{array}{l}\text { Clinical } \\
\text { information }\end{array}$ \\
\hline BRASS & 2003 & $\begin{array}{l}\text { USA, single center } \\
\text { (The Brigham and } \\
\text { Women's Hospital) }\end{array}$ & RA & $1,309[11]$ & $\begin{array}{l}\text { Drug response } \\
\text { and toxicity, } \\
\text { disease activity } \\
\text { and prognosis }\end{array}$ \\
\hline DANBIO & 2000 & Denmark & $\begin{array}{l}\text { Biologics users with } \\
\text { RA, AS, PsA }\end{array}$ & $14,249[12]$ & Drug safety \\
\hline BSRBR & 2001 & UK & $\begin{array}{l}\text { Biologics users and } \\
\text { non-users with RA; biologic } \\
\text { users with SpA, PsA }\end{array}$ & $\begin{array}{l}\text { 19,282 RA } \\
\text { biologics users [13] }\end{array}$ & Drug safety \\
\hline IORRA & 2000 & $\begin{array}{l}\text { Japan, single center } \\
\text { ('Tokyo Women's } \\
\text { Medical University) }\end{array}$ & RA & $5,637[14]$ & $\begin{array}{l}\text { Clinical } \\
\text { information }\end{array}$ \\
\hline REAL & 2005 & Japan & $\begin{array}{l}\text { Biologics users and } \\
\text { non-users with RA }\end{array}$ & $\begin{array}{l}\text { 1,068 TNF } \\
\text { inhibitor users [15] }\end{array}$ & Drug safety \\
\hline KORONA & 2008 & South Korea & RA & $5,317[16]$ & $\begin{array}{l}\text { Clinical } \\
\text { information }\end{array}$ \\
\hline KOBIO & 2012 & South Korea & $\begin{array}{l}\text { Biologics users and } \\
\text { non-users with RA; } \\
\text { biologics users with AS, PsA }\end{array}$ & 1,227 RA [17] & $\begin{array}{l}\text { Drug safety and } \\
\text { effectiveness }\end{array}$ \\
\hline
\end{tabular}

RA, rheumatoid arthritis; CORRONA, consortium of Rheumatology Researchers of North America; BRASS, Brigham and Women's Hospital Rheumatoid Arthritis Sequential Study; DANBIO, nationwide registry of biological therapies in Denmark; AS, ankylosing spondylitis; PsA, psoriatic arthritis; BSRBR, British Society for Rheumatology Biologics Register; SpA, spondyloarthropathy; IORRA, Institute of Rheumatology Rheumatoid Arthritis by Tokyo Women's Medical University; REAL, Registry of Japanese Rheumatoid Arthritis Patients on Biologics for Long-term safety; TNF, tumor necrosis factor; KORONA, Korean Observational Study Network for Arthritis; KOBIO, Korean nationwide Biologics.

${ }^{a}$ Number of patients based on the last published article.

Korean RA patients: disability [57,58], comorbidity [59], and mortality [6o]. The Biologics Pharmacoepidemiology Study (BIOPSY) for RA patients which can be merged with the KORONA database was established in 2011, and produced a study of the comparative effectiveness of biologic and conventional DMARDs [61]. In 2012, the Korean nationwide registry, Korean College of Rheumatology Biologics and targeted therapy Registry (KOBIO) for several rheumatic diseases such as RA, ankylosing spondylitis (AS), and PsA was launched by Korean College of Rheumatology [62]. This registry is a multi-centre, prospective, observational program that gathers and analyzes data on patients being treated with biologic agents and small molecules in Korea. As of September 10, 2018, those patients who were requested by each rheumatologist had consented to participate in the cohort and a total of 1,881 RA, 1,731 AS, and 62 PsA patients had been included in KOBIO (http://rheum. inforang.co.kr/kobio/).

\section{PUBLISHED TOPICS IN STUDIES FROM MAJOR PROSPECTIVE RA COHORTS AND REGISTRIES}

To identify research topics derived from data in cohorts and registries, articles were extracted from PubMed as search words 'the name of cohort' AND 'rheumatoid arthritis' using a total of six cohorts and registries. We reviewed individual articles selected from each cohort and registry as of September 2018: CORRONA ( $\mathrm{n}=$ 
Table 2. Main outcomes of published papers using representative RA cohorts and registries

\begin{tabular}{|c|c|c|c|c|c|c|}
\hline Cohort & $\begin{array}{c}\text { CORRONA } \\
(\mathrm{n}=8 \mathrm{l})\end{array}$ & $\begin{array}{l}\text { IORRA } \\
(n=48)\end{array}$ & $\begin{array}{l}\text { KORONA } \\
(\mathrm{n}=11)\end{array}$ & $\begin{array}{l}\text { BSRBR } \\
(n=38)\end{array}$ & $\begin{array}{c}\text { DANBIO } \\
(\mathrm{n}=85)\end{array}$ & $\begin{array}{c}\text { KOBIO } \\
(\mathrm{n}=3)\end{array}$ \\
\hline Country & US & Japan & Korea & US & Denmark & Korea \\
\hline RA activity and remission & 28 & 3 & 1 & 4 & 14 & 1 \\
\hline Disability and quality of life & 2 & 9 & 2 & o & 11 & o \\
\hline Comparative effectiveness & 5 & o & 1 & 4 & 1 & o \\
\hline Comorbidity & 12 & 11 & 2 & 4 & 8 & $\mathrm{o}$ \\
\hline Patient-reported outcomes & 3 & o & 1 & 0 & 3 & 0 \\
\hline Compliance & 1 & O & o & o & 3 & o \\
\hline Drug effectiveness & 7 & 7 & 0 & 4 & 22 & 0 \\
\hline Drug safety & 11 & 5 & o & 19 & 9 & 1 \\
\hline Mortality & 1 & 2 & 0 & 1 & 0 & 0 \\
\hline Other $^{\mathrm{a}}$ & 12 & 11 & 4 & 6 & 15 & 1 \\
\hline
\end{tabular}

RA, rheumatoid arthritis; CORRONA, Consortium of Rheumatology Researchers of North America; IORRA, Institute of Rheumatology and Rheumatoid Arthritis of Tokyo Women's Medical University; KORONA, Korean Observational Study Network for Arthritis; BSRBR, British Society for Rheumatology Biologics Register; DANBIO, nationwide registry of biological therapies in Denmark; KOBIO, Korean nationwide Biologics.

${ }^{a}$ Others: description of the database, descriptive or validation study, methodologic issues, economic analysis, medical accessibility, or pathogenesis.

96), IORRA ( $\mathrm{n}=54), \operatorname{KORONA}(\mathrm{n}=11), \operatorname{BSRBR}(\mathrm{n}=44)$, DANBIO (nationwide registry of biological therapies in Denmark; $n=98)$, and KOBIO $(n=3)$, to identify the clinical research performed using each database. Then the main topics of studies using these databases were classified into 10 categories: (1) RA disease activity and remission, (2) disability and quality of life, (3) comparative effectiveness of drugs, (4) comorbidities, (5) PRO, (6) compliance, (7) drug effectiveness, (8) drug safety, (9) mortality, and (10) "other" including description of the database, methodologic issues, economic analysis, medical accessibility and pathogenesis, etc. (Table 2). According to their main outcomes as shown in Table 1, work based on the CORRONA and IORRA cohorts has focused on RA activity and disability or comorbidity, while work on BSRBR and DANBIO have focused on drug effectiveness and safety.

\section{A NEW PARADIGM FOR OUTCOMES IN RA COHORTS AND REGISTRIES}

Next, the frequency of articles in each research category were arranged in chronologic order to detect trends in the main outcomes of clinical research (Fig. 1). The most significant recent changes have been increasing research on disease remission and PRO. Many studies related to drug safety and effectiveness were published after the introduction of biologic DMARDs and the number of such studies peaked after biologic agents had been in use for a long time. Clinical studies related to these topics will continue to appear due to the introduction of new drugs in clinical practice. In addition, there has recently been a focus on specific comorbidities such as interstitial lung diseases and depression, while papers on well-known comorbidities such as osteoporosis and fracture were published in the early period.

We would now like to discuss possible future initiatives for obtaining valuable evidences for improving patients' treatment through clinical research using existing cohorts or newly established cohorts. Treatment paradigms have changed in response to evidence from clinical trials and observational data. With the advent of biologic DMARD therapies and T2T approaches we aim to achieve remission and dream of obtaining cures. At the same time, we continue to strive to improve care and better understand treatment choices. The 


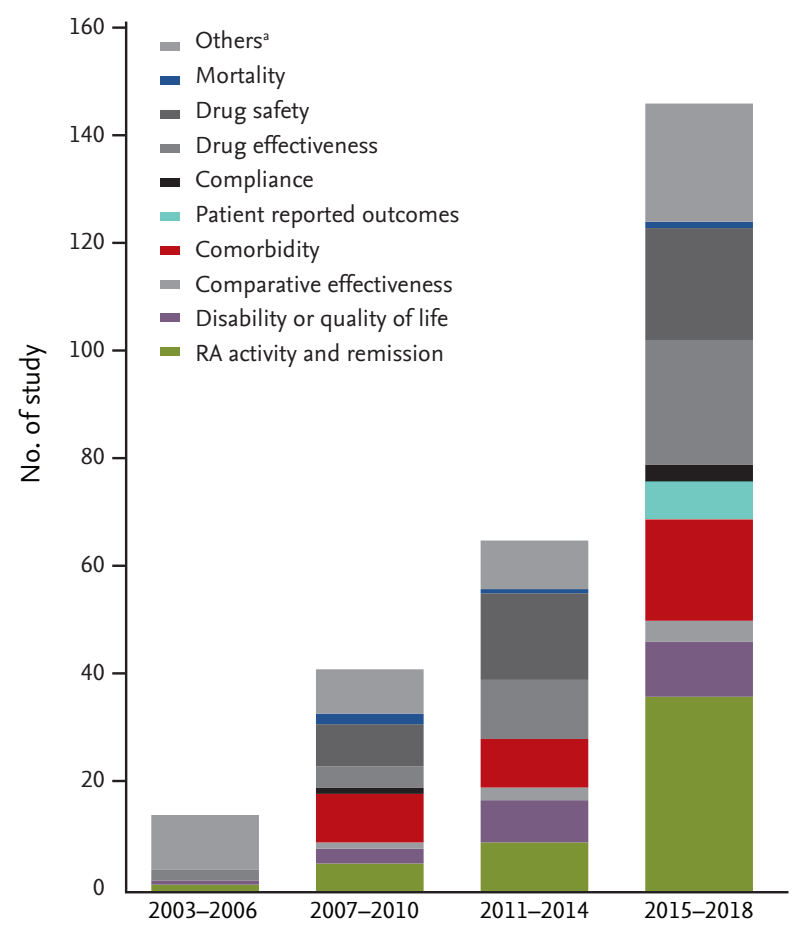

Figure 1. Chronologic changes of study issues using representative rheumatoid arthritis (RA) cohorts and registries including Consortium of Rheumatology Researchers of North America (CORRONA), Institute of Rheumatology and Rheumatoid Arthritis of Tokyo Women's Medical University (IORRA), Korean Observational Study Network for Arthritis (KORONA), British Society for Rheumatology Biologics Register (BSRBR), nationwide registry of biological therapies in Denmark (DANBIO), and Korean nationwide Biologics (KOBIO). ${ }^{\mathrm{a} O t h e r s: ~ d e s c r i p t i o n ~ o f ~ t h e ~ d a t a b a s e, ~ d e s c r i p t i v e ~ o r ~}$ validation study, methodologic issues, economic analysis, medical accessibility, or pathogenesis, etc.

much greater attention to PRO as the main outcome is one of the significant shifts in clinical research. It is important for physicians to consider the condition of patients outside the hospital, because judging patients' condition on the basis of single hospital visits may lead to inconsistency between physicians' and patients' disease assessments. From this perspective, remote technology-based monitoring systems for PRO are being highlighted in the US and Europe. Such systems can also provide important data that can be integrated into patients' health records $[6,56]$. Data are vital for advancing knowledge, and technology has the potential to transform the data we can collect about RA and how it is presented to advance care [63]. In this regard, collab- orative studies among national databases and data linkage within individual nations [64] can be crucial. They are now paying great attention to applying databases of patient medical records and laboratory and imaging results not only for research but also for machine learning and 'artificial intelligence.' Thus complex clinical data are becoming more meaningful and relevant to decision making in clinical practice. Furthermore, tailored medicine and drug repositioning can also become possible through plentiful clinical studies combined with genetic information on individual patients. In addition, these studies will be useful in preventive research through the study of risk factors and of aggravating factors in the early stages of RA.

\section{CONCLUSIONS}

In recent decades, enormous prospective RA cohorts and registries have been developed and have generated information about disease activity in patients, disability, and the safety of treatments. These studies have improved the course of disease and contributed significantly to establishing safe and effective treatment strategies. Recently, there has been a gradual shift to PRO and specific comorbidities as the major outcomes of clinical research using cohort databases. In addition, big database that include PRO based on reports from outside the hospital environment as well as wide spectrum clinical information can be put to use in decision making in clinical practice.

In accordance with these changes, efforts to loosen the boundary between PRO in cohort data and electronic medical records and to share information more widely are needed. In this way patient-physician communication and the decision making process will be improved, and should lead to better disease outcomes in RA patients.

\section{Conflict of interest}

No potential conflict of interest relevant to this article was reported.

\section{Acknowledgments}

This research was supported by a grant of the Korea Health Technology R\&D Project through the Korea 
Health Industry Development Institute (KHIDI), funded by the Ministry of Health and Welfare, Republic of Korea (grant number: HI16Coo61).

\section{REFERENCES}

1. Furner SE, Hootman JM, Helmick CG, Bolen J, Zack MM. Health-related quality of life of US adults with arthritis: analysis of data from the behavioral risk factor surveillance system, 2003, 2005, and 2007. Arthritis Care Res (Hoboken) 2011;63:788-799.

2. Gladman DD, Farewell VT. Longitudinal cohort studies. J Rheumatol Suppl 2005;72:30-32.

3. Garrison L, McDonnell ND. Etanercept: therapeutic use in patients with rheumatoid arthritis. Ann Rheum Dis 1999;58 Suppl 1:I65-I69.

4. Willke RJ, Burke LB, Erickson P. Measuring treatment impact: a review of patient-reported outcomes and other efficacy endpoints in approved product labels. Control Clin Trials 2004;25:535-552.

5. Smolen JS, Landewe R, Breedveld FC, et al. EULAR recommendations for the management of rheumatoid arthritis with synthetic and biological disease-modifying antirheumatic drugs: 2013 update. Ann Rheum Dis 2014;73:492-509.

6. Kremer JM. The Corrona US registry of rheumatic and autoimmune diseases. Clin Exp Rheumatol 2016;34(5 Suppl 101):S96-S99.

7. Cho SK, Kim D, Sung YK. Observational cohort studies in rheumatic diseases. Korean J Med 2014;87:548-556.

8. Kremer J. The CORRONA database. Ann Rheum Dis 2005;64 Suppl 4:iv37-iv41.

9. Iannaccone CK, Lee YC, Cui J, et al. Using genetic and clinical data to understand response to disease-modifying anti-rheumatic drug therapy: data from the Brigham and Women's Hospital Rheumatoid Arthritis Sequential Study. Rheumatology (Oxford) 2011;50:40-46.

10. Yamanaka H, Tohma S. Potential impact of observational cohort studies in Japan on rheumatoid arthritis research and practice. Mod Rheumatol 2006;16:75-76.

11. Alemao E, Guo Z, Frits ML, Iannaccone CK, Shadick NA, Weinblatt ME. Association of anti-cyclic citrullinated protein antibodies, erosions, and rheumatoid factor with disease activity and work productivity: a patient registry study. Semin Arthritis Rheum 2018;47:630-638.

12. Hetland ML, Jensen DV, Krogh NS. Monitoring patients with rheumatoid arthritis in routine care: experiences from a treat-to-target strategy using the DANBIO registry. Clin Exp Rheumatol 2014;32(5 Suppl 85):S-141-S-146.

13. Rutherford AI, Subesinghe S, Hyrich KL, Galloway JB. Serious infection across biologic-treated patients with rheumatoid arthritis: results from the British Society for Rheumatology Biologics Register for Rheumatoid Arthritis. Ann Rheum Dis 2018;77:905-910.

14. Yano K, Ikari K, Inoue E, et al. Features of patients with rheumatoid arthritis whose debut joint is a foot or ankle joint: a 5,479-case study from the IORRA cohort. PLoS One 2018;13:e0202427.

15. Sakai R, Cho SK, Nanki T, et al. The risk of serious infection in patients with rheumatoid arthritis treated with tumor necrosis factor inhibitors decreased over time: a report from the registry of Japanese rheumatoid arthritis patients on biologics for long-term safety (REAL) database. Rheumatol Int 2014;34:1729-1736.

16. Han M, Sung YK, Cho SK, et al. Factors associated with the use of complementary and alternative medicine for Korean patients with rheumatoid arthritis. J Rheumatol 2015;42:2075-2081.

17. Jung SM, Kwok SK, Ju JH, et al. Risk factors associated with inadequate control of disease activity in elderly patients with rheumatoid arthritis: results from a nationwide Korean College of Rheumatology BIOlogics (KOBIO) registry. PLoS One 2018;13:e0205651.

18. Tutuncu Z, Reed G, Kremer J, Kavanaugh A. Do patients with older-onset rheumatoid arthritis receive less aggressive treatment? Ann Rheum Dis 2006;65:1226-1229.

19. Ranganath VK, Paulus HE, Onofrei A, et al. Functional improvement after patients with rheumatoid arthritis start a new disease modifying antirheumatic drug (DMARD) associated with frequent changes in DMARD: the CORRONA database. J Rheumatol 2008;35:1966-1971.

20. Greenberg JD, Reed G, Kremer JM, et al. Association of methotrexate and tumour necrosis factor antagonists with risk of infectious outcomes including opportunistic infections in the CORRONA registry. Ann Rheum Dis 2010;69:380-386.

21. Navarro-Millan I, Chen L, Greenberg JD, Pappas DA, Curtis JR. Predictors and persistence of new-onset clinical remission in rheumatoid arthritis patients. Semin Arthritis Rheum 2013;43:137-143.

22. Ranganath VK, Maranian P, Elashoff DA, et al. Comorbidities are associated with poorer outcomes in community 
patients with rheumatoid arthritis. Rheumatology (Oxford) 2013;52:1809-1817.

23. Mease PJ, Karki C, Palmer JB, et al. Clinical characteristics, disease activity, and patient-reported outcomes in psoriatic arthritis patients with dactylitis or enthesitis: results from the Corrona Psoriatic Arthritis/Spondyloarthritis Registry. Arthritis Care Res (Hoboken) 2017;69:1692-1699.

24. Sato M, Schneeweiss S, Scranton R, et al. The validity of a rheumatoid arthritis medical records-based index of severity compared with the DAS28. Arthritis Res Ther 2006;8:R57.

25. Karlson EW, Chibnik LB, Cui J, et al. Associations between human leukocyte antigen, PTPN22, CTLA4 genotypes and rheumatoid arthritis phenotypes of autoantibody status, age at diagnosis and erosions in a large cohort study. Ann Rheum Dis 2008;67:358-363.

26. Lee YC, Cui J, Lu B, et al. Pain persists in DAS28 rheumatoid arthritis remission but not in ACR/EULAR remission: a longitudinal observational study. Arthritis Res Ther 2011;13:R83.

27. Prince FH, Bykerk VP, Shadick NA, et al. Sustained rheumatoid arthritis remission is uncommon in clinical practice. Arthritis Res Ther 2012;14:R68.

28. Lillegraven S, Prince FH, Shadick NA, et al. Remission and radiographic outcome in rheumatoid arthritis: application of the 2011 ACR/EULAR remission criteria in an observational cohort. Ann Rheum Dis 2012;71:681-686.

29. Lillegraven S, Paynter N, Prince FH, et al. Performance of matrix-based risk models for rapid radiographic progression in a cohort of patients with established rheumatoid arthritis. Arthritis Care Res (Hoboken) 2013;65:526-533.

30. Doyle TJ, Dellaripa PF, Batra K, et al. Functional impact of a spectrum of interstitial lung abnormalities in rheumatoid arthritis. Chest 2014;146:41-50.

31. Brown LE, Frits ML, Iannaccone CK, Weinblatt ME, Shadick NA, Liao KP. Clinical characteristics of RA patients with secondary SS and association with joint damage. Rheumatology (Oxford) 2015:54:816-820.

32. Radner H, Yoshida K, Mjaavatten MD, et al. Development of a multimorbidity index: impact on quality of life using a rheumatoid arthritis cohort. Semin Arthritis Rheum 2015;45:167-173.

33. Liao KP, Playford MP, Frits M, et al. The association between reduction in inflammation and changes in lipoprotein levels and HDL cholesterol efflux capacity in rheumatoid arthritis. J Am Heart Assoc 2015;4:eoo1588.
34. Ahmad HA, Alemao E, Guo Z, et al. Association of low bone mineral density with anti-citrullinated protein antibody positivity and disease activity in established rheumatoid arthritis: findings from a US observational cohort. Adv Ther 2018;35:232-242.

35. Hellgren K, Dreyer L, Arkema EV, et al. Cancer risk in patients with spondyloarthritis treated with TNF inhibitors: a collaborative study from the ARTIS and DANBIO registers. Ann Rheum Dis 2017;76:105-111.

36. Askling J, Fored CM, Geborek P, et al. Swedish registers to examine drug safety and clinical issues in RA. Ann Rheum Dis 2006;65:707-712.

37. Hetland ML, Unkerskov J, Ravn T, et al. Routine database registration of biological therapy increases the reporting of adverse events twentyfold in clinical practice. First results from the Danish Database (DANBIO). Scand J Rheumatol 2005;34:40-44.

38. Lie E, Fagerli KM, Mikkelsen K, et al. First-time prescriptions of biological disease-modifying antirheumatic drugs in rheumatoid arthritis, psoriatic arthritis and axial spondyloarthritis 2002-2011: data from the NOR-DMARD register. Ann Rheum Dis 2014;73:1905-1906.

39. Silman A, Symmons D, Scott DG, Griffiths I. British society for rheumatology biologics register. Ann Rheum Dis 2003;62 Suppl 2:ii28-ii29.

40. Dixon WG, Watson K, Lunt M, et al. Rates of serious infection, including site-specific and bacterial intracellular infection, in rheumatoid arthritis patients receiving anti-tumor necrosis factor therapy: results from the British Society for Rheumatology Biologics Register. Arthritis Rheum 2006;54:2368-2376.

41. Forsblad-d'Elia H, Bengtsson K, Kristensen LE, Jacobsson LT. Drug adherence, response and predictors thereof for tocilizumab in patients with rheumatoid arthritis: results from the Swedish biologics register. Rheumatology (Oxford) 2015;54:1186-1193.

42. Askling J, Baecklund E, Granath F, et al. Anti-tumour necrosis factor therapy in rheumatoid arthritis and risk of malignant lymphomas: relative risks and time trends in the Swedish Biologics Register. Ann Rheum Dis 2009;68:648-653.

43. Raaschou P, Soderling J, Turesson C, Askling J; ARTIS Study Group. Tumor necrosis factor inhibitors and cancer recurrence in Swedish patients with rheumatoid arthritis: a nationwide population-based cohort study. Ann Intern Med 2018;169:291-299. 
44. Wadstrom H, Frisell T, Askling J; Anti-Rheumatic Therapy in Sweden (ARTIS) Study Group. Malignant neoplasms in patients with rheumatoid arthritis treated with tumor necrosis factor inhibitors, tocilizumab, abatacept, or rituximab in clinical practice: a nationwide cohort study from Sweden. JAMA Intern Med 2017;177:1605-1612.

45. 45. Mercer LK, Galloway JB, Lunt M, et al. Risk of lymphoma in patients exposed to antitumour necrosis factor therapy: results from the British Society for Rheumatology Biologics Register for Rheumatoid Arthritis. Ann Rheum Dis 2017;76:497-503.

46. 46. Michaud K, Berglind N, Franzen S, et al. Can rheumatoid arthritis (RA) registries provide contextual safety data for modern RA clinical trials? The case for mortality and cardiovascular disease. Ann Rheum Dis 2016;75:1797-1805.

47. Curtis JR, Jain A, Askling J, et al. A comparison of patient characteristics and outcomes in selected European and U.S. rheumatoid arthritis registries. Semin Arthritis Rheum 2010;40:2-14.

48. Askling J, Berglind N, Franzen S, et al. How comparable are rates of malignancies in patients with rheumatoid arthritis across the world? A comparison of cancer rates, and means to optimise their comparability, in five RA registries. Ann Rheum Dis 2016;75:1789-1796.

49. Mercer LK, Regierer AC, Mariette X, et al. Spectrum of lymphomas across different drug treatment groups in rheumatoid arthritis: a European registries collaborative project. Ann Rheum Dis 2017;76:2025-2030.

50. Nakajima A, Kamitsuji S, Saito A, et al. Disability and patient's appraisal of general health contribute to depressed mood in rheumatoid arthritis in a large clinical study in Japan. Mod Rheumatol 2006;16:151-157.

51. Tanaka E, Mannalithara A, Inoue E, et al. Efficient management of rheumatoid arthritis significantly reduces long-term functional disability. Ann Rheum Dis 2008;67:1153-1158.

52. Shidara K, Hoshi D, Inoue E, et al. Incidence of and risk factors for interstitial pneumonia in patients with rheumatoid arthritis in a large Japanese observational cohort, IORRA. Mod Rheumatol 2010;20:280-286.

53. Yamada T, Nakajima A, Inoue E, et al. Incidence of malignancy in Japanese patients with rheumatoid arthritis. Rheumatol Int 2011;31:1487-1492.
54. Komano Y, Tanaka M, Nanki T, et al. Incidence and risk factors for serious infection in patients with rheumatoid arthritis treated with tumor necrosis factor inhibitors: a report from the Registry of Japanese Rheumatoid Arthritis Patients for Longterm Safety. J Rheumatol 2011;38:1258-1264.

55. Sakai R, Cho SK, Nanki T, et al. Head-to-head comparison of the safety of tocilizumab and tumor necrosis factor inhibitors in rheumatoid arthritis patients (RA) in clinical practice: results from the registry of Japanese RA patients on biologics for long-term safety (REAL) registry. Arthritis Res Ther 2015;17:74.

56. Sung YK, Cho SK, Choi CB, et al. Korean Observational Study Network for Arthritis (KORONA): establishment of a prospective multicenter cohort for rheumatoid arthritis in South Korea. Semin Arthritis Rheum 2012;41:745-751.

57. Cho SK, Sung YK, Choi CB, et al. Do patients with elderly-onset rheumatoid arthritis have severe functional disability? Semin Arthritis Rheum 2012;42:23-31.

58. Kim D, Choi CB, Lee J, et al. Impact of early diagnosis on functional disability in rheumatoid arthritis. Korean J Intern Med 2017;32:738-746.

59. Kim D, Cho SK, Choi CB, et al. Incidence and risk factors of fractures in patients with rheumatoid arthritis: an Asian prospective cohort study. Rheumatol Int 2016;36:1205-1214.

6o. Kim D, Cho SK, Choi CB, et al. Impact of interstitial lung disease on mortality of patients with rheumatoid arthritis. Rheumatol Int 2017;37:1735-1745.

61. Sung YK, Cho SK, Kim D, et al. Comparative effectiveness of treatment options after conventional DMARDs failure in rheumatoid arthritis. Rheumatol Int 2017;37:975-982.

62. Park DJ, Choi SJ, Shin K, et al. Switching profiles in a population-based cohort of rheumatoid arthritis receiving biologic therapy: results from the KOBIO registry. Clin Rheumatol 2017;36:1013-1022.

63. Dixon WG, Michaud K. Using technology to support clinical care and research in rheumatoid arthritis. Curr Opin Rheumatol 2018;30:276-281.

64. Curtis JR, Chen L, Bharat A, et al. Linkage of a de-identified United States rheumatoid arthritis registry with administrative data to facilitate comparative effectiveness research. Arthritis Care Res (Hoboken) 2014;66:1790-1798. 